Jurnal e-Clinic (eCl), Volume 4, Nomor 1, Januari-Juni 2016.

\title{
Survei kesehatan tenggorokan siswa SD Inpres 10/73 Pandu
}

\author{
${ }^{1}$ Giovanny G. Theno \\ ${ }^{2}$ Agustien Y. Tamus \\ ${ }^{2}$ Ronaldy E. C. Tumbel
}

\author{
${ }^{1}$ Kandidat Skripsi Fakultas Kedokteran Universitas Sam Ratulangi Manado \\ ${ }^{2}$ Bagian/SMF Telinga Hidung Tenggorok-Bedah Kepala Leher Fakultas Kedokteran \\ Email: thenogracia@gmail.com
}

\begin{abstract}
Due to modernization, people tend to become careless about the importance of health, therefore, health problems increase; one of them is throat disease. Tonsils consist of lymphoid tissue and have important function against infection either through the air or food. This study aimed to obtain the throat health status of students at Inpres 10/73 Pandu Elementary School. This was a descriptive observational study with a cross sectional approach. Respondents were 18 students of Inpres 10/73 Pandu Elementary School, consisted of 8 boys and 10 girls. The results showed that all respondents had normal color tonsils. On examination of the tonsil surfaces, 16 children (88.89\%) had normal results and 2 children $(11.11 \%)$ had pathological results. On examination of the tonsil sizes, 13 children $(72.22 \%)$ had normal results and 5 children (27.78\%) had pathological results. On examination of the pharynx, 16 children (88.89\%) had normal results and 2 children (11.11\%) had pathological results. Conclusion: Most of the students of Inpres 10/73 Pandu Elementary School had normal throat health status
\end{abstract}

Keywords: health survey, throat examination

\begin{abstract}
Abstrak: Seiring dengan perkembangan zaman, kepedulian terhadap kesehatan menjadi menurun sehingga muncul berbagai masalah kesehatan antara lain penyakit tenggorokan. Tonsil merupakan kumpulan jaringan limfoid yang berfungsi penting dalam pertahanan tubuh terhadap infeksi baik melalui udara maupun makanan. Penelitian ini bertujuan untuk mendapatkan gambaran kesehatan tenggorok pada siswa-siswi Sekolah Dasar Inpres 10/73 Pandu. Penelitian ini menggunakan metode deskriptif survei dengan pendekatan potong lintang. Responden ialah siswa-siswi Sekolah Dasar Inpres 10/73 Pandu sejumlah 18 anak, terdiri dari 8 laki-laki dan 10 perempuan. Pada hasil pemeriksaan warna tonsil didapatkan semuanya normal. Pada pemeriksaan permukaan tonsil didapatkan 16 anak $(88,89 \%)$ memiliki hasil normal dan 2 anak (11,11\%) lainnya patologis. Pada pemeriksaan ukuran tonsil, didapatkan 13 anak normal (72,22\%) dan 5 anak (27,78\%) patologis. Pada pemeriksaan faring, didapatkan 16 anak ((88,89\%) normal dan 2 anak (11,11\%) patologis. Simpulan: Sebagian besar hasil pemeriksaan pada pada siswa-siswi Sekolah Dasar Inpres 10/73 Pandu adalah normal
\end{abstract}

Kata kunci: survei kesehatan, pemeriksaan tenggorok

Pada zaman modern, seiring dengan perkembangan ilmu pengetahuan dan teknologi telah muncul berbagai masalah kesehatan akibat kurangnya pengetahuan dan kepedulian akan perilaku hidup sehat dari masyarakat. Salah satunya adalah masalah kesehatan tenggorakan. Tonsil adalah massa yang terdiri dari jaringan limfoid dan ditunjang oleh jaringan ikat dengan kriptus di dalamnya yang berfungsi sebagai sistem kekebalan tubuh. Tonsilitis adalah peradangan tonsil disebabkan oleh 
bakteri dan virus. Selain itu, faktor predisposisi timbulnya tonsilitis kronis ialah rangsangan yang menahun dari rokok, beberapa jenis makanan, higiene mulut yang buruk, pengaruh cuaca, kelelahan fisik dan pengobatan tonsillitis akut yang

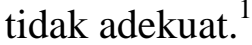

Menurut data penelitian, tonsilitis akut sering menyerang anak usia 5-15 tahun. Prevalensi tonsilitis yang disebabkan oleh bakteri khususnya streptokokus ialah 15\%$30 \%$ pada anak- anak dan 5\%-15\% pada orang dewasa. ${ }^{2}$

Berdasarkan survei epidemiologi penyakit THT di 7 provinsi di Indonesia tahun 1994-1996, prevalensi tonsilitis kronis sebesar 3,8\%, tertinggi kedua setelah nasofaring akut $(4,6 \%){ }^{3}$

Faringitis merupakan peradangan dinding faring yang disebabkan oleh virus ,bakteri, trauma dan sebagainya. Faringitis merupakan penyakit yang umum terjadi pada dewasa dan anak-anak. Kira-kira 15$30 \%$ kasus faringitis terjadi pada anak-anak usia sekolah dan $10 \%$ kasus pada orang dewasa. ${ }^{4}$ Di Indonesia pada tahun 2004 dilaporkan bahwa kasus faringitis akut masuk dalam sepuluh besar kasus penyakit yang dirawat jalan dengan persentase jumlah penderita $1,5 \%$ atau sebanyak 214.781 orang (Departemen Kesehatan, 2004). ${ }^{5}$ Siswa Sekolah Dasar (SD) yang masih dalam masa pertumbuhan rentan terinfeksi penyakit, salah satunya adalah penyakit tenggorokan. Salah satu faktor penyebabnya adalah konsumsi makanan tidak higienis. Hal ini disebabkan karena kurangnya informasi dan edukasi akan hal tersebut.

Penelitian ini bertujuan untuk mendapatkan gambaran kesehatan tenggorokan di SD Instruksi Presiden (Inpres) 10/73 Pandu.

\section{METODE PENELITIAN}

Penelitian ini menggunakan metode deskriptif observasional dengan desain potong lintang dan dilakukan pada tanggal 16 Oktober 2015. Populasi penelitian ialah siswa SD Inpres 10/73 Pandu. Responden penelitian ialah siswa kelas V SD Inpres
10/73 Pandu yang bersedia mengikuti penelitian. Penelitian ini dilakukan dengan memeriksa tenggorokan secara langsung untuk mendapatkan status kesehatan tenggorokan. Variabel penelitian yaitu ukuran tonsil, permukaan tonsil, warna tonsil, warna faring, dan gambaran faring.

\section{HASIL PENELITIAN}

Hasil penelitian yang telah dilakukan pada 16 Oktober 2015 pada siswa kelas V SD Inpres 10/73 Pandu mengenai kesehatan tenggorok, disajikan dalam bentuk tabel.

Tabel 1. Distribusi jenis kelamin responden

\begin{tabular}{ccc}
\hline $\begin{array}{c}\text { Jenis } \\
\text { Kelamin }\end{array}$ & $\mathrm{N}$ & $\mathbf{( \% )}$ \\
\hline Laki - laki & 8 & 44,44 \\
Perempuan & 10 & 55,56 \\
total & 18 & 100,00 \\
\hline
\end{tabular}

Tabel 2. Distribusi pemeriksaan warna tonsil

\begin{tabular}{ccc}
\hline Warna & $\mathrm{N}$ & $\%$ \\
Tonsil & & 100 \\
\hline Normal & 18 & 0 \\
Hiperemis & 0 & 100 \\
Total & 18 & \\
\hline
\end{tabular}

Tabel 3. Distribusi pemeriksaan permukaan tonsil

\begin{tabular}{ccc}
\hline Permukaan tonsil & $\mathrm{N}$ & $\%$ \\
\hline Normal & 16 & 88,89 \\
Kripta lebar & 2 & 11,11 \\
Kasar & 0 & 0 \\
Detritus & 0 & 0 \\
Total & 18 & 100,00 \\
\hline
\end{tabular}

Tabel 4. Distribusi pemeriksaan ukuran tonsil

\begin{tabular}{ccc}
\hline $\begin{array}{c}\text { Ukuran } \\
\text { Tonsil }\end{array}$ & $\mathrm{N}$ & $\%$ \\
\hline T0/T0 & 0 & 0 \\
T1/T1 & 13 & 72,22 \\
T2/T2 & 1 & 5,56 \\
T2/T1 & 2 & 11,11 \\
T3/T3 & 0 & 0 \\
T3/T4 & 1 & 5,56 \\
T4/T4 & 1 & 5,56 \\
TOTAL & 18 & 100,00 \\
\hline
\end{tabular}


Jurnal e-Clinic (eCl), Volume 4, Nomor 1, Januari-Juni 2016.

Tabel 5. Hasil pemeriksaan faring

\begin{tabular}{ccc}
\hline Faring & Jumlah & $\%$ \\
\hline Normal & 16 & 88,89 \\
Hiperemis & 0 & 0 \\
Granula & 1 & 5,56 \\
SDE & 1 & 5,56 \\
TOTAL & 18 & 100.00 \\
\hline
\end{tabular}

\section{BAHASAN}

Berdasarkan survei kesehatan tenggorokan yang telah dilakukan pada siswa SD Inpres 10/73 Pandu yang diikuti oleh 18 orang siswa yang bersedia menjadi responden penelitian dengan jumlah anak perempuan sebanyak 10 orang dan jumlah anak laki-laki sebanyak 8 orang didapatkan sebagian besar responden terlihat hasil pemeriksaan normal.

Pada pengamatan warna tonsil dari siswa SD 10/73 Pandu didapatkan sebanyak 18 orang (100\%) memiliki warna tonsil yang normal. Hiperemis pada tonsil biasanya terjadi pada anak yang mengalami peradangan di tonsil seperti tonsillitis. Tonsilitis adalah proses peradangan pada tonsil yang dapat disebabkan oleh virus atau bakteri yang lebih sering menyerang anak-anak dibandingkan dengan orang dewasa. ${ }^{6}$

Pada pemeriksaan permukaan tonsil pada siswa SD 10/73 Pandu didapatkan sebanyak 16 anak (88,9\%) memiliki permukaan tonsil normal dan sebanyak 2 anak memiliki permukaan tonsil yang patologis. Kedua anak tersebut memiliki permukaan tonsil dengan kripta melebar. Tonsil berada dalam kapsul yang sebagian besar terletak dalam fosa tonsil dengan perantaraan jaringan ikat jarang. Setiap folikel mempunyai kanal (saluran) yang bermuara di permukaan tonsil. Muara tersebut tampak sebagai lubang-lubang yang dinamakan kripta. Akibat radang dari folikel, tonsil membengkak dan terbentuk eksudat yang masuk keluar sebagai kotoran putih pada kripta yang dinamakan detritus. ${ }^{7}$

Pada pemeriksaan ukuran tonsil pada siswa SD Inpres 10/73 Pandu didapatkan sebanyak 13 orang memiliki ukuran tonsil yang normal yaitu klasifikasi T1/T1 dan sebanyak 5 orang memiliki ukuran tonsil yang tidak normal yang terdiri sebagai berikut 2 orang memiliki ukuran tonsil T2/T1, 1 orang memiliki ukuran tonsil T2/T2, 1 orang memiliki ukuran tonsil T4/T3, dan 1 orang lagi memiliki ukuran tonsil T4/T4. Hasil penelitian yang dilakukan oleh Palandeng et al. ${ }^{8}$ pada tahun 2014 mengenai penderita tonsilitis di poliklinik THT-KL BLU RSUP Prof. Dr. R. D. Kandou Manado Januari 2010Desemebr 2012 menunjukkan kelompok umur 5-14 tahun ialah kelompok umur terbanyak menderita tonsilitis persentase 25,90\%.

Pada pemeriksaan gambaran faring pada Siswa SD Inpres 10/73 Pandu dengan total sampel 18 orang siswa, didapatkan sebanyak 16 siswa memiliki mukosa faring yang normal sedangkan 2 orang lainnya memiliki faring patologis dengan rincian 1 orang memiliki faring SDE dan 1 orang siswa memiliki faring bergranula. Faringitis akut adalah suatu penyakit peradangan faring yang sifatnya akut. Radang ini menyerang lapisan mukosa dan submukosa faring dan disebut faringitis kronis bila radangnya sudah berlangsung dalam waktu lama dan biasanya tidak disertai gejala yang berat. ${ }^{9}$

Penelitian serupa yang dilakukan tahun 2014 oleh Kojongian et al. ${ }^{10}$ pada anakanak Eben Haezar I mendapatkan semua anak memiliki faring normal sedangkan di SD GMIM Bitung Amurang didapatkan hanya 13 anak yang memiliki faring normal dan 5 anak memilki faring bergranula. ${ }^{10}$ Hal ini juga dapat menyimpulkan bahwa kurangnya informasi akan kesehatan tenggorok menjadi salah satu faktor penyakit tenggorokan.

Hasil penelitian ini sesuai dengan hasil penelitian di atas yang menyangkut gambaran akan kesehatan tenggorok pada anak-anak. Anak-anak sangat rentan terkena penyakit yang menyangkut kesehatan tenggorok, terutama anak-anak berusia 5 sampai 14 tahun. ${ }^{11}$ Siswa Sekolah Dasar yang masih dalam masa pertumbuhan rentan terinfeksi penyakit, salah satunya ialah penyakit tenggorok. 
Salah satu faktor penyebabnya ialah konsumsi makanan tidak higienis. Hal ini disebabkan karena kurangnya informasi dan edukasi akan hal tersebut.

Limitasi penelitian ini ialah jumlah sampel yang sedikit sehingga belum dapat digunakan sebagai tolak ukur untuk gambaran kesehatan tenggorokan secara umum.

\section{SIMPULAN}

Hasil survei kesehatan tenggorok yang dilakukan pada siswa kelas V SD Inpres 10/73 Pandu meliputi pemeriksaan ukuran tonsil, permukaan tonsil, warna tonsil, warna faring, dan gambaran faring umumnya memiliki gambaran kesehatan tenggorok yang baik.

\section{SARAN}

Disarankan bagi pemerintah untuk mengadakan penyuluhan mengenai betapa pentingnya kesehatan tenggorok kepada masyarakat khususnya anak-anak.

\section{DAFTAR PUSTAKA}

1. Soetjipto D, Mangunkusumo E, Wardani R. Odinofagi. In: Rusmarjono, Hermani, editor. Buku Ajar Ilmu Kesehatan Telinga Hidung Tenggorok Kepala Leher (7th ed). Jakarta: Balai Penerbit FKUI Jakarta, 2012.

2. Wald ER, Green MD, Schwartz B, et al. A Streptpcoccal score card revisited. Pediart Emerg care. 1998;14:109-11.

3. Wiyanto, Pelealu, Tumbel. Survei Kesehatan Tenggorokan di Desa Tinoor. e-Clinic. 2015;3(1):594.
4. Sanpardi, Dehoop J, Mengko SK. Survei Kesehatan Tenggorok pada Masyarakat Pesisir Pantai Bahu. eClinic. 2015;3(1):550.

5. Rusmarjono, Kartosoediro S. Odinofagi. In: Buku Ajar Ilmu Penyakit Telinga Hidung Tenggorok Kepala Leher. Jakarta: Balai Penerbit FKUI, 2007.

6. Sidell D. Infect Disord Drug Targets. 2012. [Cited 6 Januari 2016]. Available from:

http://www.ncbi.nlm.nih.gov/pubmed /22338587

7. Herawati SJPB, Sri Rukmini S. Penyakit Telinga Hidung Tenggorok. In: Lilian Juwono, editor. Buku Ajar Ilmu Penyakit Telinga Hidung Tenggorok untuk Mahasiswa Fakultas Kedokteran Gigi. Jakarta: EGC, 2003.

8. Palandeng A, Dehoop J, Tumbel R. Penderita Tonsilitis di Poliklinik THT-KL BLU RSUP Prof. DR.R.D Kandou Manado Januari 2010Desember 2012. e-Clinic. 2014;2(2).

9. Ballenger JJ, Snow JB. Ballenger's Otrorhinolaryngonology Head and Neck Surgery (6th ed). Spain: BC Decker Inc., 2003.

10.Kojongian S, Pelealu $O$, Tumbel $R$. Kesehatan tenggorokan pada siswa Sekolah Dasar Eben Haezar I Manado dan Sekolah Dasar GMIM Bitung Amurang Kabupaten Minahasa Selatan. e-Clinic. 2014;2(1).

11.Thios RL. Profil Penderita Tonsilitis di Poliklinik THT-KL BLU RSUP Prof. Dr. R. D. Kandou - Manado, Januari 2008 - Desember 2010. Manado: Universitas Sam Ratulangi; 2011. 